\title{
THE IMPACT OF ACCELERATOR DATING AT THE EARLY VILLAGE OF ABU HUREYRA ON THE EUPHRATES
}

\author{
A. M. T. MOORE \\ Yale University, Graduate School, 1504A Yale Station, New Haven, Connecticut 06520-7425 USA
}

\begin{abstract}
The early village of Abu Hureyra is significant because of its great size (ca. 11.5 ha) and long sequence of occupation (ca. 11,500-7000 BP) that spans the transition from late Pleistocene hunting and gathering to early Holocene farming, and the cultural change from Epipaleolithic to Neolithic. The 40 accelerator dates obtained for Abu Hureyra provide new information on the development of agriculture in Southwest Asia. The dates have demonstrated that the site was inhabited for much longer than the few conventional radiocarbon dates for the site had suggested. The gap between the Epipaleolithic and Neolithic villages seems to have been brief. A change in climate and vegetation, dated at $c a .10,600$ $\mathrm{BP}$, during the span of occupation of the Epipaleolithic village, precipitated an adjustment in the foraging way of life of its inhabitants just before the inception of agriculture. Dating of individual bones and seeds has shown that the wild progenitors of sheep and several cereals were present near Abu Hureyra in the late Pleistocene and early Holocene, well outside their present areas of distribution. This has implications for where those species may have been domesticated. A rapid switch from exploitation of the gazelle to herding of sheep and goats during the Neolithic occupation occurred ca. 8300 BP.
\end{abstract}

\section{THE SITE AND ITS SIGNIFICANCE}

Abu Hureyra was a very large prehistoric settlement mound (11.5 ha) in the Euphrates Valley of northern Syria. It consisted of two superimposed villages, Abu Hureyra 1, inhabited by late Epipaleolithic sedentary hunter-gatherers, and Abu Hureyra 2, an early Neolithic community of farmers. There was a brief hiatus in occupation between the two. The remains of the Abu Hureyra 2 village, consisting of the debris from numerous mudbrick houses, comprised the bulk of the deposits in the mound.

Abu Hureyra is significant because it was occupied for an unusually long period of time during the transition from foraging to farming, one of the major transformations in human existence. The information recovered from the site has illuminated the course of this fundamental change in human society and economy, and the context in which it occurred. The great size of the Abu Hureyra 2 settlement and its cultural remains are a remarkable testament of the immediate consequences of the new way of life for early farming communities.

The site was excavated in 1972 and 1973 during a campaign of salvage excavations that preceded the completion of a dam across the Euphrates (Moore 1975). Intense analysis of the artifacts and organic remains from the excavation has taken place in the last decade, and it is this research that has provided the framework for the series of radiometric dates discussed here, all of which are uncalibrated.

\section{THE DATING PROGRAM}

Southwest Asia was one of the most important centers of agricultural genesis, but the contribution of the ancient inhabitants of Syria to this process was unknown because few sites of the Epipaleolithic and early Neolithic periods had been discovered there before the excavation of Abu Hureyra. The site had the potential to enlarge our understanding of the cultural sequence from Epipaleolithic to Neolithic and the transition from foraging to farming. An important need was to obtain a series of dates for Abu Hureyra in order to establish when and for how long it had been inhabited. The British Museum Radiocarbon Laboratory dated a series of charcoal samples from Abu Hureyra soon after the completion of the excavation (Fig. 1; Table 1). Those dates provided 


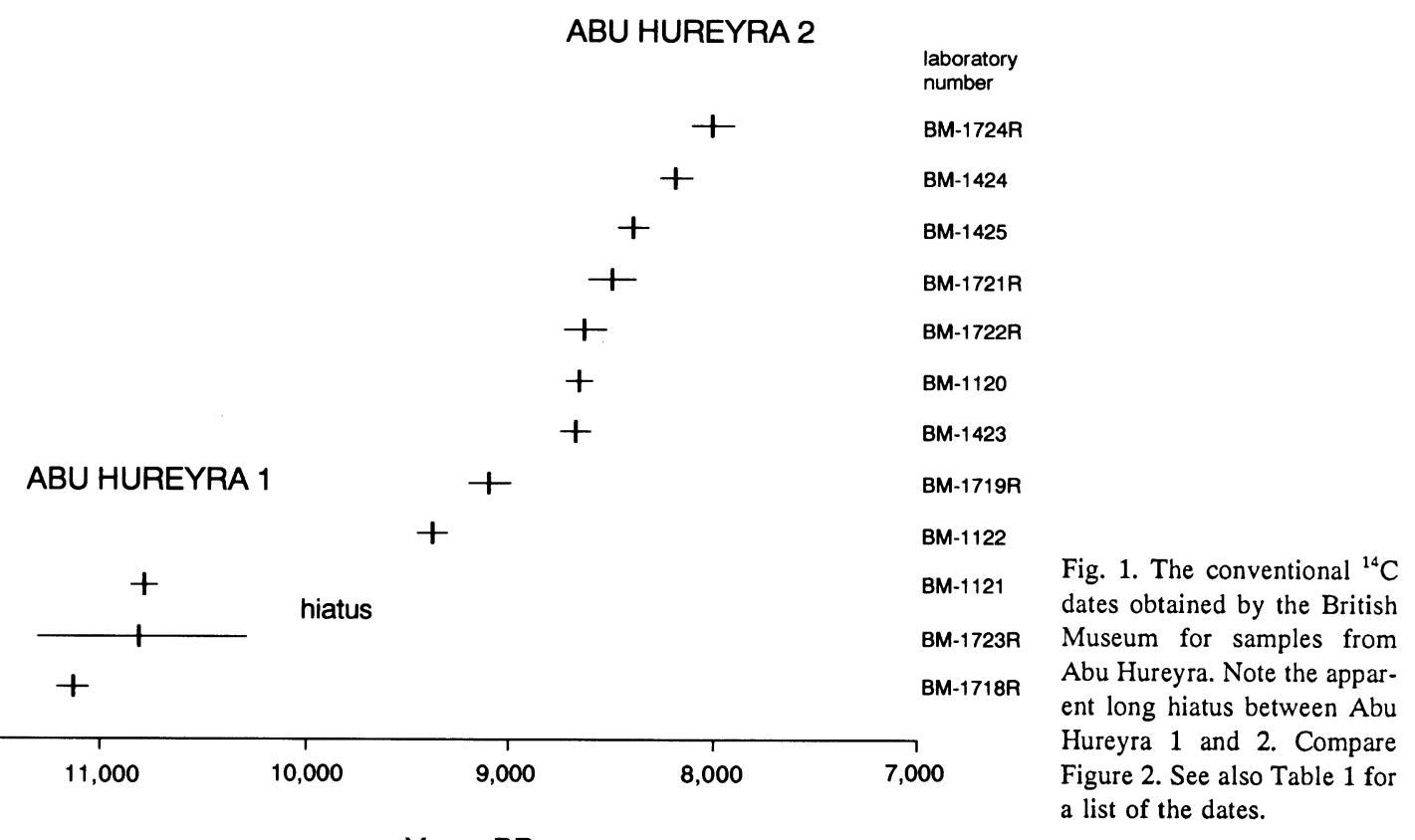

Years BP

a general chronology for the site that confirmed its great antiquity and the presence of two distinct superimposed settlements, but they raised other problems that required solution. It was not possible to determine from the dates precisely how long Abu Hureyra 1 and 2 had been occupied. The hiatus between the settlements appeared to have lasted 1400 years, thus suggesting that a considerable period of time had elapsed between the two periods of occupation. That had important implications for the speed of the transition from foraging to farming. Our research had raised other questions concerning the domestication of plants and animals in the northern Levant that called for much more precise dating of Abu Hureyra and the organic remains recovered from it. Unfortunately, there were no more samples of charcoal large enough to date satisfactorily by the conventional ${ }^{14} \mathrm{C}$ method, so it seemed that we would be unable to resolve these problems.

The advent of accelerator mass spectrometry (AMS) provided a means of obtaining a much more detailed chronology for Abu Hureyra. Because the method could date directly exceedingly small samples of seeds and bones, it could answer our further questions concerning when agriculture developed. In collaboration with the Research Laboratory for Archaeology and the History of Art at the University of Oxford, my colleagues and I have since obtained 40 AMS dates for Abu Hureyra (Table 1). The program was carried out in stages, so that we could take into account the results obtained for each successive group of samples when selecting further material for dating. The Oxford laboratory dated a few samples several times for experimental purposes, and some of the dates duplicated ones that had already been obtained. The balance of over 30 dates may resolve the archaeological problems.

\section{THE PRINCIPAL RESULTS}

An important initial result of the dating program was a good correspondence between the Oxford and the British Museum dates where they could be compared directly (Moore et al. 1986). Thus, the problem of interlaboratory discrepancy between the two sets of dates did not arise. 


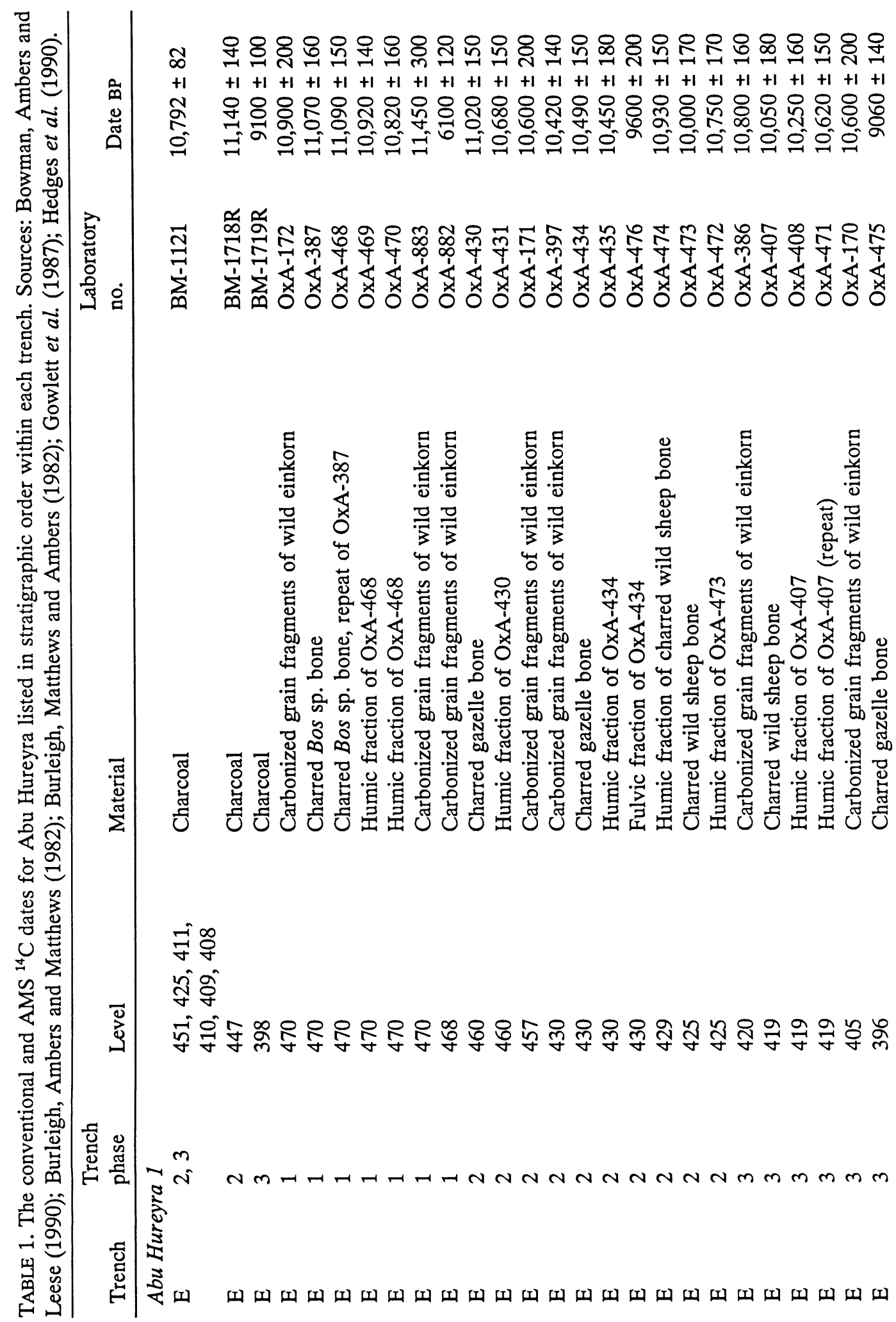




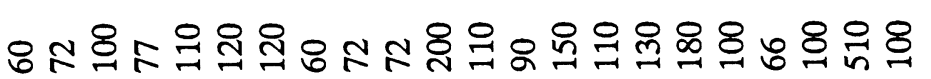
$+1+1+1+1+1+1+1+1+1+1+1+1+1+1+1+1+1+1+1+1+1+1$

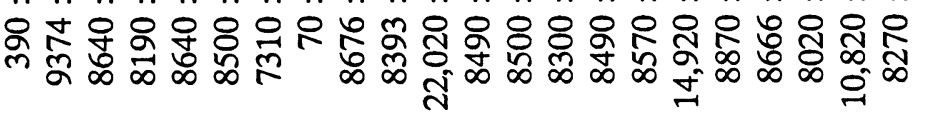

8.8 $+1+1+1$

四

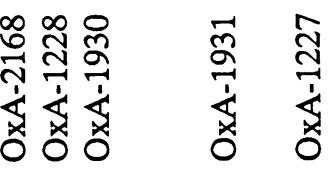

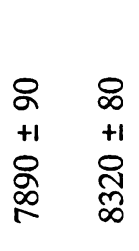

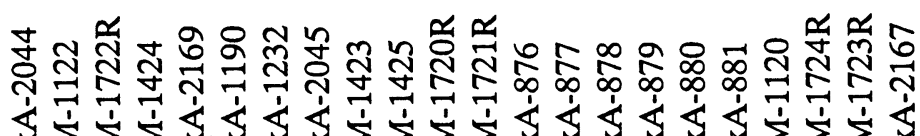

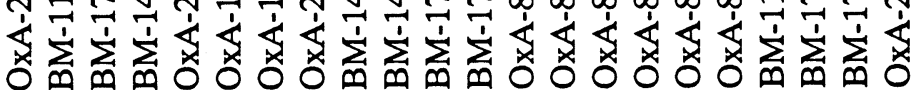
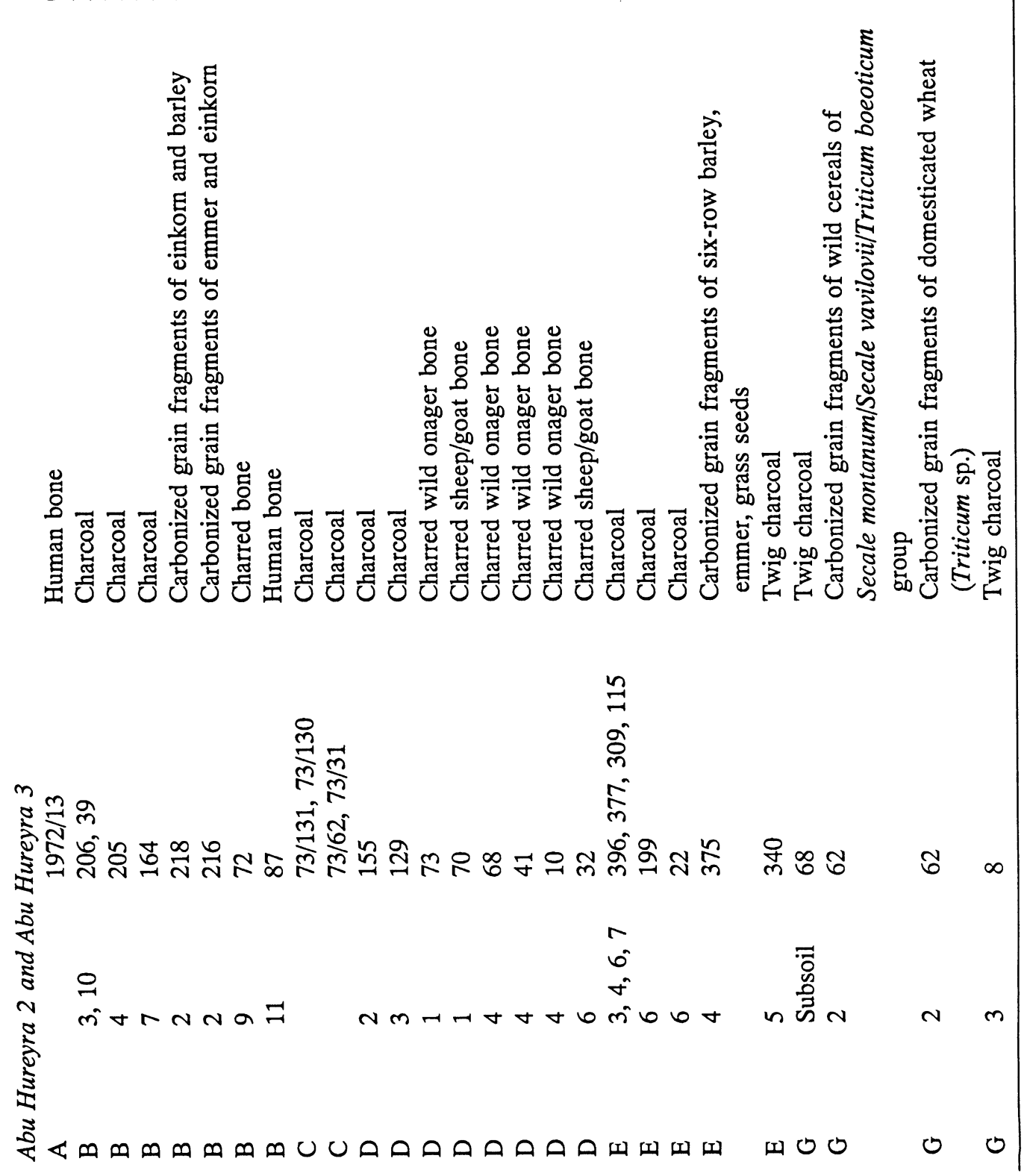
The recent correction of laboratory errors by the British Museum did not significantly alter their dates for Abu Hureyra (Bowman, Ambers \& Leese 1990: 77).

The AMS dates indicated that Abu Hureyra had been occupied for considerably longer than we had expected (ca. 11,500-7000 BP; Fig. 2). Abu Hureyra 1 was inhabited for about 1500 years (ca. $11,500-10,000 \mathrm{BP}$ ), a very long time for a site of the Epipaleolithic period, and Abu Hureyra 2 for nearly three millennia (ca. 9700-7000 BP). Our estimate for the end of occupation at Abu Hureyra is based in part on thermoluminescence (TL) dates on pottery obtained by the Oxford Laboratory (Huxtable, personal communication 1987). Further, the AMS dates suggest that only 300 years elapsed between the end of Abu Hureyra 1 and the beginning of Abu Hureyra 2, a much shorter period of abandonment than the British Museum dates had indicated. The stratigraphic evidence suggests, however, that the site was occupied only intermittently between 9700 and $9000 \mathrm{BP}$. Abu Hureyra 2 then flourished as a large village for fully two millennia, according to the AMS dates.

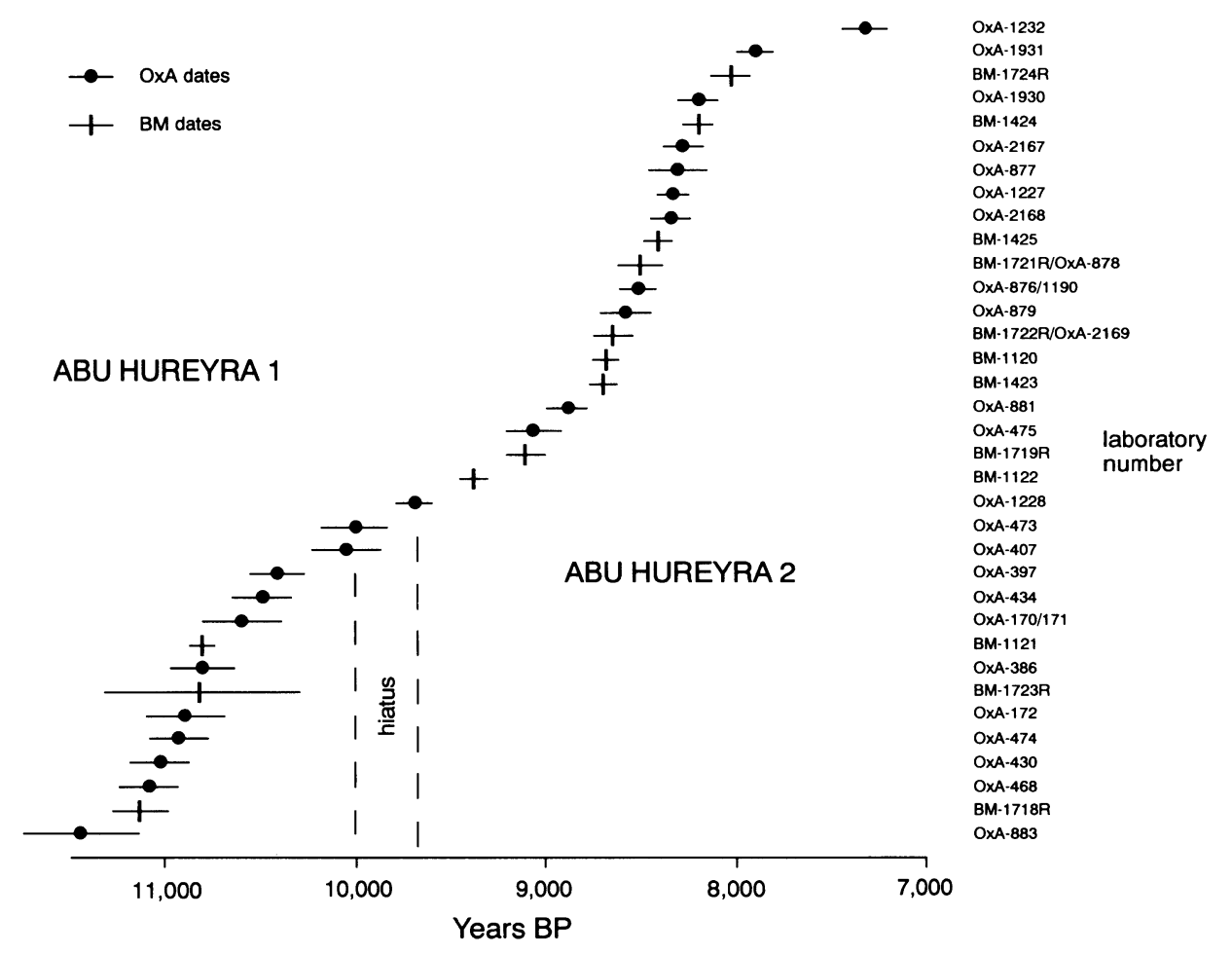

Fig. 2. The Oxford AMS and British Museum conventional ${ }^{14} \mathrm{C}$ dates for Abu Hureyra. Note that the hiatus between Abu Hureyra 1 and 2 was of brief duration. See also Table 1 for a list of the dates.

Abu Hureyra was so large that our seven excavation trenches were spaced as much as $100 \mathrm{~m}$ apart. That made it difficult to correlate the stratigraphic sequences of phases in each trench. It was necessary to use all available kinds of information that documented change through time, especially changes in the structures and artifacts, and alterations in the use of plants and animals, in order to determine the history of occupation across the whole site. The AMS dates have helped us to date such changes, and so to provide an absolute chronology for the sequence of occupation at Abu Hureyra. We have been able to determine the history of the successive settlements at Abu Hureyra, period by period, and to date their duration (Fig. 3). 


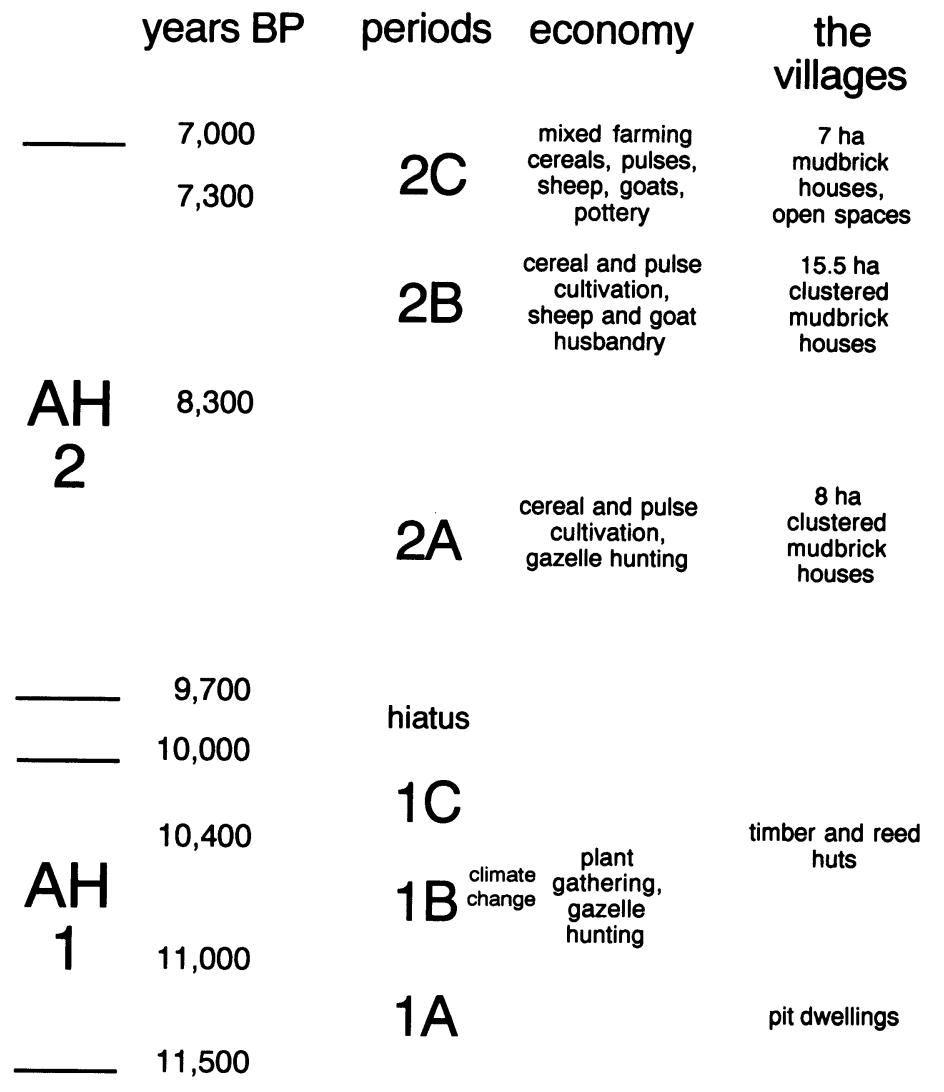

Fig. 3. The sequence of occupation at Abu Hureyra and the characteristics of the successive periods

Abu Hureyra 1 was inhabited long enough for changes to have occurred in the way of life of its inhabitants that we might expect to detect. These would be of special interest because the site was occupied on the eve of the advent of agriculture. Thus, any changes we could discern might throw light on that process. We discovered that alterations did indeed take place in the form of the settlement and in the artifacts (Moore 1991). The spectrum of plants collected by the inhabitants also varied during the life of the village of Abu Hureyra 1, because a change occurred in the climate that altered the extent of vegetation zones in the vicinity (Hillman, Colledge \& Harris 1989: Fig. 14.1). Abu Hureyra 1 was inhabited during the Late Glacial, a period of climatic amelioration, when the atmospheric temperature was increasing worldwide. The climate fluctuated, however, during this period, as records from other regions of the world indicate (Goudie 1983). During the Younger Dryas ( $c a$. 11,000-10,000 BP), a climatic episode first defined in the European vegetation record (Iversen 1954), the climate became cooler and drier. This event has recently been recognized in a new pollen core obtained from the Huleh Basin in the upper Jordan Valley (Baruch \& Bottema 1991). It apparently corresponds with the change in vegetation that we have detected in the record from Abu Hureyra 1 (Moore \& Hillman 1992). During period 1A at Abu Hureyra, the climate was relatively moist; thus the inhabitants were able to gather fruits of hackberry and Pistacia trees, as well as seeds of wild einkorn and rye, all of which apparently grew within walking distance of the site. Then, according to plant remains recovered from the site, the quantities of tree fruits and seeds of wild cereals declined sharply early in period $1 \mathrm{~B}$, to be replaced by more steppic species. Evidently, the climate became drier, and the plants that preferred 
moister conditions retreated from the vicinity of Abu Hureyra. Using AMS dates, we have been able to estimate the date of the impact of the climatic change on the inhabitants to be about 10,600 BP, during the Younger Dryas. The event is of special significance, because it seems to have put pressure on the gathering system, obliging the inhabitants to alter their plant-collecting habits. The resulting stress, when combined with other factors, led to the temporary abandonment of the site. The climate change may also have contributed to the switch from foraging to farming. That, in turn, required the domestication of cereals and legumes, events that seem to have happened during the brief interval when Abu Hureyra was abandoned.

A major change in the animal economy took place during the occupation of Abu Hureyra 2. The people of Abu Hureyra $2 \mathrm{~A}$ were cultivators who grew domesticated cereals and pulses, but they still hunted large numbers of gazelle that migrated past the site each spring (Legge \& RowleyConwy 1987). Later, they killed far fewer gazelle and relied instead on domesticated sheep and goats for the bulk of their meat. The stratigraphic evidence indicates that this switch occurred quite suddenly right across the site. We have used this important change as the main means of distinguishing between periods $2 \mathrm{~A}$ and $2 \mathrm{~B}$ at Abu Hureyra. The AMS dates from several of the trenches allowed us to define quite precisely the moment at which it happened.

The transition itself occurred during Phase 8 in Trench B. A charcoal date of $8190 \pm 77 \mathrm{BP}$ (BM-1424) for Phase 7 preceded it. The entire sequence of Trench D belongs within period 2A at Abu Hureyra, that is, before the switch from gazelle to sheep and goats; the latest date there is $8300 \pm 150 \mathrm{BP}(\mathrm{OxA}-877)$ on an ovicaprid bone. The Abu Hureyra 2 deposits in Trench E, on the other hand, belong almost entirely within 2B, after the switch. The earliest AMS date there is 8330 \pm 100 BP (OxA-2168) on twig charcoal. Finally, a set of dates from the sequence in Trench $G$ again, falls almost completely within $2 \mathrm{~B}$; the oldest date there is $8320 \pm 80 \mathrm{BP}$ (OxA-1227), also on twig charcoal. These dates suggest that the change from gazelle hunting to large-scale sheep and goat herding took place about $8300 \mathrm{BP}$. The change marked the final adoption of the full Neolithic way of life at Abu Hureyra, that is, a subsistence economy based almost exclusively on domesticated cereals and pulses, and herded sheep and goats.

Our evidence indicates that the successive changes in the two settlements at Abu Hureyra and the economy of their inhabitants took place in a series of steps. The people of Abu Hureyra 1 were hunters and gatherers who were obliged to modify their way of life in part because of climatic change. Their successors in Abu Hureyra $2 \mathrm{~A}$ were farmer-hunters, and in $2 \mathrm{~B}$ and $2 \mathrm{C}$, farmerherders. The AMS dates indicate that the passage from one economic and cultural stage to the next at Abu Hureyra occurred rapidly. Thus, the full Neolithic way of life at Abu Hureyra developed over a long period of time, but it happened through a series of swift adjustments followed by episodes of consolidation. This view of the adoption of farming contrasts with the traditional interpretation that farming developed gradually (compare, for example, Flannery 1969; Redman 1978: 142).

The AMS dates have provided valuable information on the dates when particular species of plants and animals came into use at the site (Moore et al. 1986: 1071). We have been able to pursue this aspect of the dating program simply because AMS can date such exceedingly small samples. Thus, we have dated a series of wild einkorn grains that demonstrate this cereal was used throughout the Abu Hureyra 1 sequence. Wild einkorn does not grow near Abu Hureyra today because the climate is too dry and perhaps too warm. The confirmation that it grew near the site then indicates that the environment was moister, at least during the growing season, and probably cooler. The presence of wild einkorn in the plant remains from Abu Hureyra 1 also suggests that this cereal was domesticated close by in northern Syria during the few centuries that Abu Hureyra was abandoned, 
since it was among the domesticated plants found in the earliest levels of Abu Hureyra 2. Thus, domestication of einkorn and, perhaps, several of the pulses native to the region probably took place early in the tenth millennium BP. On this reasoning, agriculture would have commenced about the same time in the northern Levant as farther south, where remains of domesticated plants were recovered from Jericho and Tell Aswad in levels dating to the centuries around 10,000 BP (Hopf 1983; van Zeist \& Bakker-Heeres 1985).

Most of the cereals found in levels throughout the Abu Hureyra 2 sequence were domesticated. Interestingly enough, however, one sample from Abu Hureyra 2B, level 62 in Trench $G$, has yielded abundant grains of both wild and domesticated cereals. The date for the wild cereals (rye and einkorn) is $8180 \pm 100 \mathrm{BP}$ (OxA-1930), and for the domesticated wheat, $7890 \pm 90 \mathrm{BP}$ (OxA-1931). Thus, it appears that wild cereals continued to be collected, on occasion at least, until late in the Abu Hureyra sequence. The dates also indicate that wild cereals were still growing near the site as late as $8000 \mathrm{BP}$, implying that the climate was still moister than at present during the growing season.

The domestication history of sheep has long been a matter of controversy. The Asiatic mouflon, Ovis orientalis, the wild ancestor of domestic sheep, lives today in the foothills and mountains of Asia Minor and the Zagros chain. Based on this distribution, it was thought that sheep were domesticated in the Zagros and then spread to the rest of Southwest Asia (Ryder 1984: 66, 68). Thus, the discovery of bones of sheep in Abu Hureyra 1 challenged the conventional view by raising the possibility that the distribution of sheep had been significantly different in the late Pleistocene than in the present (Legge \& Rowley-Conwy 1986). To resolve this issue, we needed to be sure that the sheep bones were of the same age as the deposits in which they occurred. Two charred sheep bones yielded dates of 10,050 $\pm 180 \mathrm{BP}$ (OxA-407) and 10,000 $\pm 170 \mathrm{BP}$ (OxA-473), and the humic fraction of a third, a date of $10,930 \pm 150 \mathrm{BP}(\mathrm{OxA}-474)$. These dates confirmed that the bones did indeed belong in the context in which they were found. When other recent early finds of sheep in the Levant are taken into account, it becomes clear that the distribution of this species in the late Pleistocene extended throughout the Levant and onto the steppic plains (Legge \& Rowley-Conwy 1986: 33). Thus, sheep could have been domesticated, not just in the Zagros Mountains, but anywhere around the Fertile Crescent.

Numerous human burials of relatively recent date were found in the surface deposits of Abu Hureyra. They are important because they provide a sample of human remains to compare anthropologically with the substantial number of burials from Abu Hureyra 2. Their precise date was, however, uncertain because few grave goods were found with them. Several were apparently Byzantine, on the evidence of pottery found in association with them, but the rest could not be dated archaeologically. Once again, the AMS technique was able to resolve the problem for us. We did have difficulty in finding samples with enough residual collagen for even AMS dating, but we have been able to date two skeletons. One from Trench A was dated to $390 \pm 60 \mathrm{BP}$ (OxA-2044), and another from Trench B, to $170 \pm 60$ (OxA-2045). The dates suggest that these burials took place over several centuries during the later Islamic period; their calibrated range would be from the 15 th to the early 19 th centuries $\mathrm{AD}$. It is likely that many of the other recent burials are of about the same age.

\section{OBSERVATIONS}

The AMS dates obtained for Abu Hureyra have provided an impressive demonstration of the value of the method for resolving dating problems in archaeology, archaeobotany and archaeozoology. The precision of the method and its ability to date small samples have allowed us to answer 
questions that were beyond reach a decade ago. The detailed chronology that we have been able to construct for the development of the two villages at Abu Hureyra has been of great value, not only for determining what happened at that site, but for our understanding of the late Epipaleolithic and early Neolithic in the Levant. The precise dating we now have for the successive economic changes at Abu Hureyra has implications, too, that extend far beyond the site, since they provide support for a new model of how farming developed in Southwest Asia.

\section{ACKNOWLEDGMENTS}

The research reported here has been made possible through close collaboration over many years with the British Museum Radiocarbon Laboratory and the Research Laboratory for Archaeology and the History of Art of the University of Oxford. I extend my thanks, and those of my colleagues in the Abu Hureyra project, to both institutions. This paper was written during tenure of a National Endowment for the Humanities (NEH) Fellowship for University Teachers; the support of NEH is gratefully acknowledged.

\section{REFERENCES}

Baruch, U. and Bottema, S. 1991 Palynological evidence for climatic changes in the Levant $c a .17,000-$ 9,000 BP. In Bar-Yosef, O. and Valla, F. R., eds., The Natufian Culture in the Levant. Ann Arbor, Michigan, International Monographs in Prehistory: 11-20.

Bowman, S. G. E., Ambers, J. C. and Leese, M. N. 1990 Re-evaluation of British Museum radiocarbon dates issued between 1980 and 1984. Radiocarbon 32(1): 59-79.

Burleigh, R., Ambers, J. and Matthews, K. 1982 British Museum natural radiocarbon measurements $\mathrm{XV}$. Radiocarbon 24(3): 262-290.

Burleigh, R., Matthews, K. and Ambers, J. 1982 British Museum natural radiocarbon measurements XIV. Radiocarbon 24(3): 229-261.

Flannery, K. V. 1969 Origins and ecological effects of early domestication in Iran and the Near East. In Ucko, P. J. and Dimbleby, G. W., eds., The Domestication and Exploitation of Plants and Animals. London, Gerald Duckworth: 73-100.

Goudie, A. 1983 Environmental Change, 2nd edition. Oxford, Oxford University Press: 258 p.

Gowlett, J. A. J., Hedges, R. E. M., Law, I. A. and Perry, C. 1987 Radiocarbon dates from the Oxford AMS system: Archaeometry datelist 5. Archaeometry 29(1): 125-155.

Hedges, R. E. M., Housley, R. A., Bronk, C. R. and van Klinken, G. J. 1990 Radiocarbon dates from the Oxford AMS system: Archaeometry datelist 11. Archaeometry 32(2): 211-237.

Hillman, G. C., Colledge, S. M. and Harris, D. R. 1989 Plant-food economy during the Epipalaeolithic period at Tell Abu Hureyra, Syria: Dietary diversity, seasonality, and modes of exploitation. In Harris, D. R. and Hillman, G. C., eds., Foraging and Farming. London, Unwin Hyman: 240-268.

Hopf, M. 1983 Jericho plant remains. In Kenyon, K. M. and Holland, T. A., eds., Excavations at Jericho Volume 5, Appendix B. London, British School of
Archaeology in Jerusalem: 576-621.

Iversen, J. 1954 The late-glacial flora of Denmark and its relation to climate and soil. Dansmarks Geologiske Unders $\varnothing$ gelse II(80): 87-119.

Legge, A. J. and Rowley-Conwy, P. A. 1986 New radiocarbon dates for early sheep at Tell Abu Hureyra, Syria. In Gowlett, J. A. J. and Hedges, R. E. M., eds., Archaeological Results from Accelerator Dating. Oxford, Oxford University Committee for Archaeology: 23-35.

1987 Gazelle killing in Stone Age Syria. Scientific American 257(2): 76-83.

Moore, A. M. T. 1975 The excavation of Tell Abu Hureyra in Syria: A preliminary report. Proceedings of the Prehistoric Society 41: 50-77.

1991 Abu Hureyra 1 and the antecedents of agriculture on the Middle Euphrates. In Bar-Yosef, O. and Valla, F. R., eds., The Natufian Culture in the Levant. Ann Arbor, Michigan, International Monographs in Prehistory: 277-294.

Moore, A. M. T., Gowlett, J. A. J., Hedges, R. E. M., Hillman, G. C., Legge, A. J. and Rowley-Conwy, P. A. 1986 Radiocarbon accelerator (AMS) dates for the Epipaleolithic settlement at Abu Hureyra, Syria. Radiocarbon 28(3): 1068-1076.

Moore, A. M. T. and Hillman, G. C. 1992 The Pleistocene to Holocene transition and human economy in Southwest Asia: The impact of the Younger Dryas. American Antiquity 57(3): 482-494.

Redman, C. L. 1978 The Rise of Civilization. San Francisco, W. H. Freeman: 367 p.

Ryder, M. L. 1984 Sheep. In Mason, I. L., ed., Evolution of Domesticated Animals. London, Longmans: 63-85.

van Zeist, W. and Bakker-Heeres, J. A. H. 1982 Archaeobotanical studies in the Levant 1. Neolithic sites in the Damascus Basin: Aswad, Ghoraifé, Ramad. Palaeohistoria 24: 165-256. 